\title{
ENSAIO SOBRE A CONTRAPOSIÇÃO MARXIANA À TEORIA DO GÊNIO
}

\author{
ENSAYO SOBRE LA CONTRAPOSICIÓN MARXIANA A LA TEORÍA \\ DEL GENIO
}

\author{
Alexandre de Jesus Santos \\ Universidade Estadual do Sudoeste da Bahia, Brasil \\ Jasson da Silva Martins \\ Universidade Estadual do Sudoeste da Bahia, Brasil
}

\section{Resumo}

Durante muitos séculos da história ocidental, a tradição filosófica vem atribuindo aos gênios toda a responsabilidade pela criação artística, compreendendo esta última como um desdobramento necessário e, portanto, inevitável resultante da inspiração transcendental e da personalidade peculiar característica de alguns poucos sujeitos iluminados. Em linhas gerais, os principais expoentes da história da filosofia ocidental, de Platão até Hegel, conceberam o gênio como preceptor daquelas consideradas como sendo as mais belas obras já produzidas pela humanidade. Somente a partir do segundo quartel do século XIX, Marx e Engels romperam radicalmente com esta concepção, compreendendo a arte e o artista, não como singularidades puras manifestas no mundo médium da relação entre o transcendental e o material, mas como sujeitos históricos, fruto e expressão das contradições sociais inerente às sociedades de classes.

Palavras chave: Teoria do gênio. Arte. Artista. Contradições sociais.

\section{Resumen}

Durante muchos siglos de la historia occidental, la tradición filosófica viene atribuyendo a los genios toda la responsabilidad por la creación artística, comprendiendo esta última como un desdoblamiento necesario $\mathrm{y}$, por lo tanto, inevitable resultante de la inspiración trascendental 


\section{Introdução}

y de la personalidad peculiar característica de algunos pocos sujetos iluminados. En líneas generales, los principales exponentes de la historia de la filosofía occidental, desde Platón hasta Hegel, concibieron el genio como preceptor de aquellas consideradas como las más bellas obras ya producidas por la humanidad. Sólo a partir del segundo cuartel del siglo XIX, Marx y Engels rompieron radicalmente con esta concepción, comprendiendo el arte y el artista, no como singularidades puras manifestadas en el mundo médium de la relación entre lo trascendental y el material, sino como sujetos históricos, fruto y expresión de las contradicciones sociales inherentes a las sociedades de clases.

Palabras clave: Teoría del genio. Arte. Artista. Contradicciones sociales.

A história da humanidade é repleta de peculiaridades, de acontecimentos sistemáticos e aleatórios, de causalidades, mas também de casualidades. Neste processo que se desenrola no tempo e no espaço muito já se especulou sobre as condições de possibilidade da produção artística, da genialidade e da criatividade humanas que deixaram marcas indeléveis desde as primeiras manifestações da subjetividade no âmbito das pinturas litófilas na "pré-história" até aquelas consideradas as mais belas expressões artísticas da cultura burguesa na sociedade moderna ${ }^{\mathrm{i}}$.

Sobre a particularidade deste problema uma longa tradição filosófica se desenhou propondo refletir sobre ao menos duas importantes questões: a primeira refere-se as condições da produção artísticas, a qual ousamos formular com o seguinte contorno: como a arte se produz e qual o papel do sujeito nesta produção? A segunda, não menos importante, pode ser apresenta nestes termos: teria, a arte ou o artista, algum papel relevante no interior da sociedade?

Essas duas questões indissociáveis foram objeto de reflexão de muitos pensadores ao longo da história da humanidade, ocupando consideráveis linhas das reflexões filosóficas platônicas até a consideração emblemática do problema referente ao papel da arte no sistema filosófico hegeliano e seus desdobramentos posteriores.

Estamos aludindo um longo percurso sulcado pela história da humanidade e a história da filosofia, com posicionamentos interpretativos díspares e até contraditórios entre si. A 
partir do segundo quartel do século XIX, Marx e Engels lançam um novo olhar sobre o tema esboçando algumas linhas esparsas sobre os dois problemas suscitados nas ilações precedentes.

Evidentemente, não temos a intenção de perfilar pormenorizadamente toda a tradição filosófica que se debruçou sobre o problema afim de contextualizar o objeto de investigação deste ensaio. Muito embora reconhecemos ser necessário reconstituir as considerações já realizadas sobre o objeto. Faremos da forma mais sucinta possível com fito de focar o tratamento do problema nas filosofias de Kant e Hegel para, em seguida, estabelecemos a consequente contraposição marxiana ao tema proposto e a teoria do gênio.

O problema central que constituiu objeto de reflexão deste ensaio sobre o qual nos debruçaremos doravante pode ser definido da seguinte forma: qual a concepção marxiana das condições que permitem o surgimento e desenvolvimento dos sujeitos responsáveis pela produção artística e qual o papel da arte no interior do sistema de relações sociais.

A dificuldade suscitada para realização de uma reflexão desta natureza a partir da própria obra de Marx e Engels está no fato de que nenhum desses autores escreveu um manuscrito tratando especificamente dos problemas relativos à estética. No entanto, é possível extrair uma "teoria estética" e, neste caso, ponderações relacionadas a esta problemática dispersas em diversas obras, muito embora nosso enfoque recaia quase que exclusivamente sobre A ideologia alemã de 1845-46.

\section{O problema estético nas filosofias platônica e aristotélica}

Pensar o tratamento do problema estético na antiguidade clássica é reavivar a disputa, a delimitação e a afirmação entre a arte poética, a sofísticai ${ }^{\mathrm{ii}}$ e a filosofia, cada uma pleiteando seu espaço e sua consolidação enquanto campo específico do saber humano.

Sócrates e Platão foram os principais responsáveis por esse longo processo de transição que vai do mito ao $\log o s$, ou seja, por uma delimitação daquilo que pertence ao campo de atuação da arte poética e aquilo que diz respeito especificamente à filosofia. No contexto desta disputa, fica cada vez mais evidente que a filosofia, enquanto discurso racional, vai ganhando autonomia frente à arte poética e afirmando a sua identidade. É exatamente neste processo de afirmação da identidade da filosofia socrática que encontramos as primeiras formulações relacionadas ao problema estético e é nele que vamos nos concentrar. 
Sumariamente falando, pensar sobre os condicionamentos da arte na filosofia platônica, no nosso entendimento, perpassa apreender seu lugar no conjunto do seu sistema filosófico. Por esse prisma, poderíamos dizer que a teoria do conhecimento de Platão, expressa grosso modo no dualismo entre o mundo inteligível e o mundo sensível, é substrato fundamental a partir do qual a arte deve ser analisada.

Assim, enquanto o mundo inteligível é descrito como sendo o mundo das formas perfeitas, de onde emana e para onde caminha todo o ser de acordo à teoria da reminiscência (PLATÃO, 2001; 2016a; 2008) associado à imobilidade, à perenidade e, por conseguinte, à ideia de verdade, o mundo sensível é, ao contrário, aquele no qual a corrupção se manifesta invariavelmente vinculado à noção de mutabilidade.

É considerando a estrutura, apresentada aqui de modo sumário, que vai se delineando ao longo das obras de Platão e sobretudo a partir dos diálogos socráticos, a disputa pelo domínio dos campos do saber e da afirmação da filosofia. Neste processo o autor desenvolve toda sua argumentação no sentido de delimitar e, ao mesmo tempo, desconsiderar a arte poética enquanto campo do saber próprio da atividade racional.

A atividade do poeta, o dizer e o transpor dos seus ensinamentos, bem como a transmissão dos valores e das normas sociais estabelecidas nos seus cantos, sempre foi vista com bons olhos no interior da sociedade grega. $\mathrm{O}$ espaço reservado às atividades poéticas nas festas gregas testemunha o quanto essa atividade não era referendada pela realização autônoma da subjetividade e da criatividade humana, mas, antes de tudo, o poeta era considerado um porta-voz dos deuses.

A sabedoria, ao contrário da filosofia, surge, aos olhos de Sócrates, como algo relacionado ao divino. A filosofia, por sua vez, parece alguma coisa referida ao próprio homem, que tem de haver consigo mesmo e com a linguagem na construção de um saber (OLIVEIRA, 2011, p. 12).

O autor salienta ainda que

Os belos poemas [...] cantados pelo rapsodo, ao contrário, não são humanos [...], nem provém dos homens. São divinos, provenientes dos deuses [...]. Os poetas: intérpretes desses deuses [...]. Os rapsodos: intérpretes desses intérpretes [...] (OLIVEIRA, 2011, p. 13). 
Para os objetivos deste ensaio importa considerar o tratamento dado, nos diálogos socráticos, não somente ao rapsodo Íon, no diálogo homônimo (2011), mas, também, à Hípias no Hípias Menor (2016b) e aos poetas usuários da arte mimética de forma mais generalizada como consta no livro $\mathrm{X} d$ 'A república.

O poeta, enquanto mestre da verdade, como define Marcel Detienne (2013), é uma autoridade a partir da qual os deuses se manifestam. O poeta é mestre da verdade, mas a manifesta através de uma arte mimética e inspirada. Evidentemente, Platão está tentando estabelecer um outro tipo de saber cujo fundamento não está simplesmente ancorado na tradição cantada pelos poetas e rapsodos, mas assentada em valores éticos, numa busca radicada pela verdade proveniente de uma constante e metódica reflexão anamnésica. $\mathrm{O}$ sujeito mais apto para realizar a empreitada proposta por Platão é, sem sombra de dúvidas, o filósofo.

Nesse tipo de situação, no contexto de disputa entre logos - o filosófico/humano e o inspirado/divino - surge uma diferença notável de quem profere: um discurso racionalmente instituído a partir de uma reflexão sobre determinado objeto de pesquisa e um discurso inspirado pelas musas e os deuses cujas verdades proferidas gozam de destaque no interior da Grécia, a exemplo de Homero e os declamadores de sua obra. A identidade de quem realiza o discurso, bem como o método de sua elaboração ou aquisição, incide diretamente no caráter da mensagem transmitida. Por isso, do ponto de vista platônico, a arte mimética será sempre vista com determinada desconfiança.

Como mencionamos anteriormente, essa adjetivação atribuída aos poetas no centro dos diálogos socráticos e d'A república está estritamente imbricada com o problema da teoria do conhecimento. Ora, se o mundo sensível, como afirma Platão (2001; 2016a) é uma espécie de cópia imperfeita do mundo inteligível, onde se encontra a verdade e o belo em si, alcançável somente pelo esforço reminiscente dos filósofos, as artes miméticas, são ainda mais depreciáveis que os objetos sensíveis, pois são a cópia da cópia. Assim,

A condenação da poesia, proferida no terceiro livro, encontrará aqui a necessária justificação. Mediante numerosos exemplos, Sócrates já mostrou que os poetas são, o mais das vezes, apenas mestres enganosos. Mas importa precisar que isto decorre, sobretudo, da natureza da arte que eles professam. Eles são, com efeito, simples imitadores. Ora, no que exatamente consiste a imitação? Em reproduzir a imagem de um objeto material que, por sua vez, não passa da cópia de uma ideia (BACCOU, 1965, p. 54). 
Por essa intrínseca articulação entre o papel desempenhado pelos poetas no interior da república de Platão com a teoria da reminiscência, podemos observar ao menos dois aspectos gerais que incide no papel da arte e do artista, a saber:

o primeiro aspecto denuncia, segundo a interpretação corrente aqui proposta, o papel extremamente negativo que os artistas no geral - poetas, rapsodos, pintores, escultores etc. podem desempenhar no interior da república com imitações que "dista em terceiro grau de realidade de verdade" (BACCOU, 1965, p. 54), dado sua tendência geral a degeneração da coisa mesma;

o segundo, por sua vez, nos permite inferir que, tomada como uma arte tanto inspirativa como de natureza imitativa, a mesma apresenta limites sérios para poder se pensar a criatividade humana frente aos condicionamentos antropomórficos exercidos pelas divindades no âmbito da reprodução social da antiguidade ocidental.

Assim, se considerarmos que Platão foi o maior expoente da antiguidade ao tratar do estatuto ontológico da arte e dos artistas de forma amplamente articulada com o conjunto de sua produção teórica apresentando, portanto, uma coerência interna inerente a sua teoria do conhecimento, é preciso inferir que se manifesta uma profunda negatividade em relação as artes miméticas e a figura dos artistas.

Não poderíamos deixar de perceber que, decerto, apesar dessa negatividade, nos parece plausível inferir que o poeta inspirado que compõe e o rapsodo inspirado que declama, bem como os artistas de forma geral, usam sua capacidade ${ }^{\mathrm{iii}}$ no âmbito de uma particularidade que os torna singulares associado ao fato de serem, de algum modo, porta-vozes dos deuses. Evidentemente, poderíamos tratar essa peculiaridade dos artistas em termos de genialidade, pois nos ajudará a considerar o problema na filosofia marxiana.

Compete ressaltar, ainda, que a ideia de gênio nos diálogos socráticos se relaciona diretamente com a ideia de um saber inspirado. Gênio é, portanto, não aquele que sabe, mas aquele que possui uma relação intrínseca entre o saber que profere e a inspiração que recebe, conforme aparece no diálogo Banquete (2010).

Esse mesmo problema, entretanto, ganha contornos diferenciados em Aristóteles (2015). Do mesmo modo que em Platão sua formulação estética se articula com a teoria do 
conhecimento, o tratamento do problema na filosofia aristotélica também se exprime de modo a se conectar com sua perspectiva ética.

Diferentemente de Platão que vislumbra as artes miméticas com profunda desconfiança, Aristóteles compreende que há nelas um potencial ético-pedagógico [kátharsis], uma vez que, por tratar das paixões humanas, das virtudes e dos vícios, elas possuem um potencial educativo que pode influenciar diretamente as ações. Por essa razão "a mímesis tem um sentido diverso do que possui nas outras artes ou técnicas, porque se aproxima da práxis e da ética" (CHAUÍ, 2002, p. 485).

Pinheiro (2015) chama atenção ainda para o fato de que Aristóteles não requerer da arte uma expressão ilibada da verdade, dado que seu papel é exatamente aprofundar a dramatização dos acontecimentos afim de incitar nos espectadores todos os possíveis sentimentos. Assim,

De fato, o agente primeiro da mímesis é, para Aristóteles, o poeta, ou seja, aquele que elabora uma releitura dos antigos mitos da civilização grega e que, no caso do poeta trágico, seria capaz de produzir, por meio da releitura mimética, um efeito catártico, fruto da manipulação precisa que nos levariam à depuração (kátharsis) do pavor e da compaixão evocados. Como nos explica M. Canto-Sperber, a mímesis designa a inclinação do homem a representar as coisas tal como poderiam ou deveriam ser e não como são (PINHEIRO, 2015, p. 8-9).

A perspectiva ética da tragédia permite ao espectador, conforme infere Chauí (2002), viver as paixões na sua mais profunda intensidade ao mesmo tempo em que torna possível, exatamente em função do envolvimento emocional, se libertar e se purificar de tais paixões uma vez que, conforme a doutrina da mediania de Aristóteles (2016), o caminho do meio, o equilíbrio é o que fundamenta uma conduta ética.

Vale ressaltar que, assim como a arte poética em Platão é fortemente influenciada pela participação antropomórfica na inspiração dos poetas, Aristóteles trata a questão em termos de "dom natural", afirmando que

Uma vez que a atividade mimética nos é natural, e também o uso da melodia e do ritmo [...], aqueles que, desde o início, eram naturalmente mais bem dotados [sic] para esse fim conduziram e deram, pouco a pouco, origem à poesia a partir de improvisações (ARISTÓTELES, 2015, p. 58-59 [grifo nosso]).

Evidentemente, poderíamos formular em termos gerais que se materializa, na filosofia aristotélica, não somente na poética, mas também no famoso problema XXX, I mais conhecido como $O$ homem de gênio e a melancolia (1998), a condição peculiar do gênio 
como preceptor da capacidade criativa fruto da sensibilidade apurada. Assim, a finalidade pedagógica, sobretudo da arte dramática e o papel do artista como gênio incrementador do drama afim de viabilizar a consubstanciação da catarse estética, constitui uma dimensão da concepção de Aristóteles sobre o problema aqui proposto, estando, ainda que no campo do sensível, estritamente compenetrado na ideia de gênio.

Importa salientar ainda que, em Aristóteles (2012), não há uma exclusiva relação de identidade entre a obra de arte e a coisa que ela representa, uma vez que o objeto representado, apesar de remeter a coisa em-si que representa, ele não é esta coisa, possuindo, assim, uma identidade própria como coisa em-si. Assim “[...] a figura pintada num painel é simultaneamente uma figura e um retrato e embora una e idêntica, é ambos, mas ainda assim a essência de ambas não é idêntica, sendo inclusive possível pensá-la tanto como uma figura quanto como um retrato" (ARISTÓTELES, 2012, p. 79).

De tal modo, o estagirita estabelece para arte um estatuto ontológico particular, compreendendo-a não como simulacro do real (como fizera Platão), mas como sendo uma realidade com essência manifesta em si mesma. Enquanto a filosofia platônica desconsidera a verdade da arte, em nome do ideal de verdade, a filosofia aristotélica reafirma a validade da arte na medida em que ela consegue expressar aspectos da natureza humana.

\section{Kant, Hegel, a arte e o artista}

É difícil, a partir da cristianização da filosofia ocidental, perceber traços mais substanciosos da consideração do problema estético no medievo cristão. A profunda influência impetrada pelo cristianismo nas "filosofias medievais" e a intensa extensão que essas filosofias sofrem das inferências platônicas e aristotélicas em suas formulações, subsumindo a razão à fé, instrumentalizou a filosofia e, por conseguinte, a estética passando a compreender a arte e o artista como a emanação direta da inspiração divina, da eternidade da beleza. A beleza tornou-se um transcendental do ser.

A querela existente entre os grandes estudiosos da estética medieval, relacionada com sua autenticidade na consideração do problema, mesmo considerado na totalidade da “filosofia medieval”, mas, também, sua densa articulação com as questões de natureza religiosa, nos impele a dar um salto em direção a modernidade, fazendo breves observações 
do problema estético nas filosofias de Kant e Hegel para, então, analisarmos a questão na filosofia marxiana.

Antes, porém, é preciso ressaltar que o desenvolvimento da teoria estética entre os filósofos alemães não se resume aos autores supracitados, mas, espraiou-se pela Alemanha constituindo objeto de estudo para as grandes mentes da modernidade. A teoria segundo a qual a obra de arte é produto da genialidade humana, neste sentido, vai ser peremptoriamente reafirmada - como uma característica peculiar do romantismo alemão - nos sistemas filosóficos e nas produções artísticas de Goethe e Schiller até Hegel, ganhando, em cada um desses autores contornos mais sofisticados e intricados no interior de suas proposições filosóficas. O próprio Hegel reconhece que a ideia segundo a qual "a produção do talento e do gênio aparece somente como um estado em geral e, de modo mais preciso, como estado do entusiasmo" (2001, p. 49),

[...] surgiu na Alemanha na época do assim chamado período do gênio, período que foi instituído pelas primeiras produções poéticas de Goethe e, então, pelas de Schilleriv. Em suas primeiras obras estes poetas partiram do zero ao pôr de lado todas as regras que na época eram fabricadas e ao agir intencionalmente contra elas, no que também ultrapassaram amplamente outras (HEGEL, 2011, p. 49).

Por esta perspectiva apresentada por Hegel, a teoria do gênio possui raízes profundas na Alemanha do século XVIII. Assim, mesmo numa acepção romântica na qual obra de arte é concebida como produto da atividade humana sensível, ela ainda deixa evidente em suas formulações, como dirá Hegel, lacunas quanto a manifestação do espírito e da apreensão do Absoluto no fazer artísticos, como veremos mais adiante.

Vale ressaltar que, até agora, o fazer artístico e a teoria do gênio entendidas como elemento explicativo das capacidades técnicas e cognitivas das quais somente determinados sujeitos peculiares são portadores, aparece muito claramente nas proposições filosóficas de Platão e Aristóteles. Apesar de o problema da arte e do artista estar estritamente articulados com a totalidade dos seus sistemas filosóficos, obras específicas foram construídas para considerar o problema no seu âmbito particular e geral.

De igual modo, Kant (2016) também dedicou uma de suas obras para tratar de ambos os problemas, da arte e do artista, bem como da genialidade se conduzindo no sentido de pensá- 
la como uma construção que resulta da relação entre o natural e o humano (ABBAGNANO, 2007). Assim,

Do ponto de vista do direito, somente se deveria chamar de arte a produção de algo por meio da liberdade, isto é, por meio de um arbítrio que toma a razão por fundamento de suas ações. Pois, por mais que se goste de chamar o produto das abelhas (os favos de cera construídos com regularidade) de obra de arte, isso só acontece por analogia com arte; assim que se considere, com efeito, que elas não fundam o seu trabalho em uma reflexão racional própria, diz-se que é produto de sua natureza (instinto), somente atribuindo como arte ao seu criador (KANT, 2016, p. 201).

É possível perceber em Kant (2016) uma clara distinção entre a arte como produto humano e aquilo que deriva da natureza, resultado de uma relação irrefletida. Portanto, apesar do autor inserir no centro de sua concepção de arte a dimensão racional da criação ele estabelece, ao mesmo tempo, uma distinção clara entre a arte e os demais campos do saber humano.

A arte não é qualquer coisa produzida pelo homem. Kant situa a arte entre o campo do possível e da idealização, pois formula que "só pertence à arte, nessa medida, aquilo que mesmo sabendo completamente o que tem de fazer, não possui imediatamente a capacidade de fazê-lo" (Idem, 2016, p. 201). Parece existir, assim, um certo fosso entre as capacidades humanas de realização da arte idealizada e as possiblidades concretas de materializar tal idealização.

É perceptível a relação estabelecida entre a arte, produto de uma ação desinteressada e não remunerada, agradável no seu em-si e conduzida para seu fim, ou seja, ser afortunada e o artesanato, compreendida como atividade laboral penosa, remunerada e instrumentalizada para um determinado objetivo.

O autor estabelece ainda, a seguinte tipologia:

Se a arte, adequada ao conhecimento de um objeto possível, direciona as ações para tal requeridas somente para torna-lo real, ela se chama mecânica; se, em contrapartida, tem o sentimento de prazer como seu proposito imediato, ela se chama estética. Esta última é uma arte que é ou agradável ou bela. Ela é do primeiro tipo quando tem por fim que o prazer acompanhe as representações como meras sensações; e é do segundo tipo quando tem por fim que ele as acompanhe como modos de conhecimento (KANT, 2016, p. 203, grifos do autor). 
A reprodução do parágrafo acima se faz necessário pois nele Kant realiza um primeiro esforço de definir e sistematizar o conceito de belas artes ${ }^{\mathrm{v}}$. Assim, podemos apreender que enquanto as primeiras manifestações do fazer artístico estão associadas ao elemento sensível, as belas artes, por outro lado, se vinculam ao entendimento e a aquilo que Kant chama de "faculdade de julgar reflexionante" sendo, portanto, "representação que é por sim mesmo conforme a fins e, embora sem fim, fomentam o cultivo das forças da mente para a comunicação em sociedade" (KANT, 2016, p. 203).

Assim, na Crítica da faculdade de julgar, Kant estabelece uma analogia entre as belas artes e a natureza. Nas inferências do autor, a natureza é bela na medida em que não dispõe de intencionalidade e, cuja composição não apresenta nenhuma transgressão ou coerção as regras. Algo que não carece de conceito e cuja beleza não está adjunta a percepção sensível. Do mesmo modo, as artes, para serem consideradas belas, devem seguir o mesmo padrão de existência e realização da natureza.

Kant não ignora o problema da intencionalidade na produção artísticas das belas artes. Segundo ele, quando consideramos a equiparação dessas em relação à natureza, inferindo lucidamente que "[...], mesmo que seja intencional, a finalidade nos produtos das belas artes tem de parecer não intencional; ou seja, à bela arte tem de ser considerada como natureza, ainda que, evidentemente, se tenha consciência de que ela é arte" (KANT, 2016, p. 204).

É precisamente aqui, depois de elaborar uma tipologia no que concerne à função da arte no interior da sociedade - vinculando-a ao prazer ou ao juízo reflexionante - em suas diversas manifestações que também Kant reporta à teoria do gênio como elemento explicativo e característica peculiar dos indivíduos que produzem, sobretudo, as belas artes.

Kant cria toda uma sofisticada sistematização para explicar racionalmente o que racionalmente não pode ser explicado - as belas artes e os gênios -, mas, tão-somente, vislumbrado e contemplado na sua sublime similitude com a perfeição da natureza. O autor dedica cinco longos parágrafos, aproximadamente dez laudas de sua Terceira crítica para expor a imbricada relação entre a produção artística, especificamente das belas artes, e os gênios.

O autor alemão define nos seguintes termos:

Gênio é o talento (dom natural) que dá a regra à arte. Uma vez que o talento, como faculdade produtiva inata do artista, pertence ele mesmo a natureza, poderíamos nos exprimir assim: gênio é a disposição da mente (ingenium) 
através da qual a natureza dá a regra à arte (KANT, 2016, p. 205, grifos do autor).

Em termos gerais, a similitude entre arte e a natureza que surge no mundo, pelas mãos do gênio, é entendida por Kant como sendo um artifício da própria natureza que instrumentaliza alguém - o gênio - afim de que este possa conceber a regra à arte que é, esta última, a própria regra da natureza. Segundo o autor, "as belas artes devem ser necessariamente consideradas artes do gênio" (Idem) sendo, por essa mesma razão impossível para ele, o gênio, elaborar uma explicação racional que dê conta de explicitar os mecanismos utilizados a partir dos quais originou as belas artes. Assim, Kant define quatro aspectos peculiares aos gênios, sendo eles:

1) É o talento de produzir algo para o qual nenhuma regra determinada pode ser fornecida, com nenhuma predisposição de habilidade para aquilo que pudesse ser aprendido segundo alguma regra; vê-se, por conseguinte, que a originalidade tem de ser sua primeira propriedade. 2) Que, podendo haver também um contrassenso original, seus produtos têm de ser ao mesmo tempo modelos, isto é, ser exemplares; e que, portanto, mesmo não tendo surgido ele mesmo da imitação, tem de servir a outros como tal, isto é, como padrão de medida ou regra de julgamento. 3) Que ele mesmo não pode descrever ou indicar cientificamente como cria o seu produto, a não ser dizendo que ele dá a regra enquanto natureza [...]. 4) Que a natureza, através do gênio, não dá a regra à ciência, mas sim à arte; e, mesmo assim, somente quando se trata da bela arte (KANT, 2016, pp. 205-206).

Poderíamos dizer que de sua explicação emerge, com certa estranheza, a tentativa de explicar o que para ele mesmo está no campo do inexplicável, uma vez que a relação do gênio com a produção das belas artes é tão misteriosa quanto a expressão da própria natureza.

Mais uma vez assistimos, também em Kant, a tentativa deliberada de compreender as belas expressões artísticas como resultante de um tipo de relação transcendental existente entre a natureza e homem que a própria racionalidade não dá conta de explicar, a não ser por uma tautologia, reafirmando que a produção da obra de ate guarda uma relação inexplicável de seus mecanismos de ação junto a esses homens particulares preceptores das regras da natureza.

Não menos emblemática é a forma como o problema pode ser considerado na filosofia hegeliana. Assim como a questão da arte e do artista devem ser considerados no interior das 
filosofias platônica, aristotélica e kantiana como parte constituinte da totalidade de suas proposições, no sistema filosófico hegeliano não se dá de forma diferente.

Tal qual os autores supracitados, Hegel também dedicou algumas obras para tratar da questão. Antes de entrar especificamente nas inferências do autor sobre a arte, vale salientar que no sistema lógico-ontológico deste filósofo alemão a arte desempenha um papel crucial, pois também a partir dela é possível alcançar, dentro da história, um grau específico do Absoluto.

A história, como processo de desenvolvimento e encarnação gradativa do espírito subjetivo que vai se objetivando, é locus privilegiado a partir do qual a razão se desvela e manifesta seus ardis. Neste sentido, ela desempenha um papel crucial no sistema hegeliano na medida em que o que importa efetivamente é a sistemática de desenvolvimento da razão na história.

Na medida que a história se desenvolve, a partir de um movimento dialético ancorado nos momentos de afirmação, negação e negação da negação, é o próprio espírito objetivo que vai se afirmando na história. Aquilo que anteriormente era só uma ideia abstrata inerente ao espírito humano, próprio das "realidades da psicologia humana como desejos, emoções, percepção, inteligência, imaginação, memória” (NÓBREGA, 2011, p. 68), se exterioriza em relação ao homem e se materializa enquanto categorias da história em termos de moral, direito, política etc., se tornando, a medida que a histórira se desenvolve, mais efetivas e concretas até alcançar aquilo que Hegel chama de espírito absoluto.

Neste estágio do processo de desenvolvimento dos espíritos - subjetivo e objetivo - no qual a dicotomia entre vontade e realização foi superada, o espírito se torna absoluto na medida "em que se percebe idêntico a qualquer realidade. [...]. Ele se contempla a si mesmo ao contemplar qualquer coisa" (Idem, 2011, p. 72).

Assim,

Resta dizer ainda que o Espírito Absoluto tem a apreensão do Absoluto. E porque o Absoluto e Deus são idênticos, esta é também a esfera da religião, que outra coisa não é senão o conhecimento de Deus, a apreensão do divino e do eterno (NÓBREGA, 2011, p. 73).

É precisamente aqui que a arte ganha uma posição de destaque no sistema filosófico hegeliano pois, em termos de aproximações sucessivas de acesso a esta eternidade e infinitude, além da religião e da filosofia - a partir da qual o Absoluto é plenamente 
alcançável -, a arte é uma das formas de se alcançar o Absoluto como mencionamos anteriormente.

Assim, a produção artística deve ser entendida, segundo Hegel (2011) como uma forma de acessar o Absoluto num momento em que o Absoluto ainda a não se encontra totalmente objetivado na história. As diversas manifestações artísticas, por esse prisma, são expressões das diferentes formas e conteúdos a partir das quais a arte pôde acessar o Absoluto.

Assim, mergulhando no pensamento de Schelling - que considera os antigos mitos e as obras de arte não produtos de uma imaginação irracional e sim, ao contrário, uma filosofia inconsciente, o espírito dormindo ainda na matéria - Hegel encara a obra de arte como uma expressão da subjetividade, não, todavia, do sentimento empírico que permanece necessariamente singular, mas da Ideia que tende em direção ao universal, quer dizer, que deseja poder ser comunicada a todo ser racional. É precisamente este desejo que constrange a Ideia a se expressar, quer dizer, realizar-se na natureza, ao se exteriorizar no mundo. É por isso que no único ato próprio de produção de uma obra, o artista torna-se universal visto que a sua obra propõe ao seu olhar e não conserva mais o pensamento na intimidade de sua consciência. Todavia, a expressão dá lugar à criação de uma forma sensível e não um discurso lógico.

A ideia estética torna-se, deste modo, intermediária entre o puro sentimento e a pura razão, ela é a forma de uma fenomenologia do espírito ainda inconsciente dela mesma. Assim, diferentemente daquilo que é postulado por Kant (2016), a arte não é, em hipótese alguma, inferior a beleza natural ou mesmo deve sua beleza ao fato de imitar aquilo que já é belo em si mesmo, ou seja, a natureza. Para o autor

[...] não é este aspecto da beleza exterior que torna uma obra um produto da bela arte; ela só é obra de arte quando, brotada do espírito, também pertence ao terreno do espírito, foi batizada pelo espírito e somente expõe aquilo que é formado em sintonia com o espírito. Na obra de arte o interesse humano, o valor espiritual que existe num acontecimento, num caráter individual, numa ação em sua trama e em seu desenlace é apreendida e se sobressai de modo mais puro e transparente do que no terreno da restante efetividade do não artística. Por isso a obra de arte está acima do produto natural, que não fez essa passagem pelo espírito. Assim, por exemplo, uma paisagem apresentada com sentimento e conhecimento pela pintura, como obra do espírito, assume uma posição superior à paisagem meramente natural (HEGEL, 2011, p. 51). 
Neste sentido, o autor não deixa dúvida sobre sua consideração da arte como produto da atividade humana associada ao processo de ascese do espírito como algo, efetivamente, mais belo que a própria natureza. Entretanto, se a arte desempenha o papel que permite o acesso ao Absoluto num momento da história em que o Absoluto ainda não se consubstanciou como espírito objetivo, a quem é atribuído o papel de mediar esse acesso? Evidentemente, o artista é este mediador entre o espírito subjetivo e o objetivo, pois,

[...] na medida em que a obra de arte decorre do espírito, ela necessita de uma atividade subjetiva produtora, a partir da qual provém e, enquanto seu produto, é para um outro, para a intuição e o sentimento do público. Esta atividade é a fantasia do artista (HEGEL, 2011, p. 281).

A fantasia, para o Hegel, não deve ser confundida com a imaginação, pois na medida em que esta última desempenha um papel meramente passivo, a primeira, por sua vez, é criativa, pois

A esta atividade criadora pertence inicialmente o dom e o sentido para a apreensão da efetividade e suas formas, que imprimem no espírito, por meio da escuta e da visão, as mais variadas imagens do que existe [Vorhandenen], assim como a memória conservadora do mundo colorido destas imagens multiformes (HEGEL, 2011, p. 282, grifos do autor).

Assim, o papel da fantasia, para o artista, permite que a sua produção possa ser apreendida e efetivada pela materialização da obra de arte. A obra de arte, portanto, é um desdobramento não somente da relação entre subjetividade e objetividade do espírito, mas carrega um punhado de singularidade advindas das experiências do próprio artista, de tal modo que,

\begin{abstract}
Segundo esse aspecto, o artista não deve ter apenas contemplado o mundo ao seu redor e se tornado familiar com os fenômenos exteriores e interiores, e sim muitas e grandes coisas já devem ter passado pelo seu próprio peito, seu coração já deve ter sido golpeado e movido em profundidade, ele já deve ter passado por muitas coisas e já ter vivido muitas coisas antes de ser capaz de configurar [herausbilden] em fenômenos concretos as autênticas profundidades da vida. Por isso, o gênius certamente efervescem na juventude, como foi o caso, por exemplo, de Goethe e Schiller, mas somente na idade madura e avançada pode levar a uma completude e autentica maturidade da obra de arte (HEGEL, 2011, p. 284).
\end{abstract}

Mais uma vez, entretanto, a despeito do esforço realizado pelo autor em compreender a arte como um momento de manifestação do Absoluto, mas, ao mesmo tempo, entender o artista como não sendo um mero ventrículo do espírito, uma vez que na produção artística se 
objetiva também aquilo que é peculiar ao seu produtor. Hegel recorre a teoria do gênio para explicar essa capacidade peculiar da qual apenas alguns poucos sujeitos são portadores.

Assim, Hegel adverte que "esta atividade produtiva da fantasia, por meio da qual o artista elabora [herausarbeiten] em si mesmo na forma real o em si e para si racional enquanto sua própria obra, é o que se denomina de gênio, talento e assim por diante" (2011, p. 284). Afirma ainda que

O gênio é a capacidade geral para a verdadeira produção da obra de arte bem como a energia para o desenvolvimento e o acionamento desta capacidade. Mas igualmente esta aptidão e energia são ao mesmo tempo apenas subjetivas, pois produzir [produzieren] espiritualmente apenas pode um sujeito autoconsciente, que estabelece para si como finalidade um tal produzir [Hervorbringen] (Idem).

Assim, se a obra de arte não é, com efeito, mais do que uma filosofia inconsciente e o gênio o seu ente objetivador, é preciso que a filosofia se torne consciente de si mesma e conduza à supressão da arte enquanto tal, como prescreve Hegel:

Em todas estas relações a arte é e permanecerá para nós, do ponto de vista de sua destinação suprema, algo do passado. Com isso, ela também perdeu para nós a autêntica verdade e vitalidade e está relegada à nossa representação, o que torna impossível que ela afirme sua antiga necessidade na realidade efetiva e que ocupe o seu lugar superior (HEGEL, 2011, p. 35).

Poderíamos inferir, então, que teria o gênio o mesmo fim? Esta conclusão paradoxal da estética hegeliana se deduz a partir do ponto de vista idealista que foi tomado como ponto de partida, ou seja, a arte como manifestação da Ideia na história. A estética kantiana, que encontra sua origem em um sentimento subjetivo e não na expressão de uma Ideia, não conduz - por seu turno - a este impasse na qual a arte deve proceder à sua própria dissolução. Embora o autor alemão nunca tenha proclamado a morte da política, da religião e da filosofia - muito embora tenha pronunciado o fim da história pelo advento da racionalidade absoluta -, ele prega o fim da arte como ausência de interesse pela arte e, como consequência - inferimos nós - o fim dos gênios. Como afirma Burgeois “[...] o fim é ao mesmo tempo a morte, a realização é um acabamento espiritualmente negativo, o desaparecimento, na humanidade, de um interesse verdadeiro pela arte" (2004, p. 209). 


\section{A arte e o artista como desdobramento das contradições}

Nesta breve, sumária e limitada digressão que realizamos pela tradição filosófica buscamos evidenciar as diferentes concepções de arte nos autores tratados, bem como a relação desta com seus produtores. Excetuando a tradição platônica que vê na arte um ontonegatividade dado seu caráter imitativo, vislumbrando, de algum modo o papel negativo que o gênio pode desempenhar na degeneração social, poderíamos inferir sinteticamente duas premissas gerais:

A arte pode desempenhar, no interior das relações sociais, um papel positivo, seja por seu potencial no desenvolvimento do comportamento ético mediado pela catarse, seja pela contemplação do belo como desdobramento de um imperativo moral ou, ainda, como manifestação da infinitude do espírito Absoluto na finitude e na limitação da manifestação artística;

O artista, por seu turno, produtor da arte, é sempre compreendido com um sujeito sensível-suprassensível pois, na mesma medida em que possui uma dimensão eminentemente humana-material, a peculiaridade da sua forma de ser permite-lhe acessar as dimensões mais acuradas da inspiração transcendental objetivando, através da arte, as mais belas obras artísticas que, sendo humanas, são também médiuns do "divino".

Podemos inferir, com base nisto que, ao optar por abordar estas categorias privilegiando aspectos transcendentais como elementos constituintes do fazer artístico e do próprio artista excetuando, em alguma medida, o tratamento dado por Aristóteles a ambas as categorias parte desta tradição filosófica deixou de observar a manifestação concreta, material e relacional da produção artística, do seu produtor e das condições objetivas nas quais essas categorias objetivaram-se.

Assim, Marx e Engels, em meados no século XIX, não somente postularam um rompimento radical com toda a tradição filosófica instituída até então, como também estabeleceram novos parâmetros amplamente ancorados nas condições materiais e na dimensão social da vida, a partir dos quais toda e qualquer análise sobre a arte e o artista deve-se aportar.

Antes, porém, de entrarmos neste meandro, vale retomar aqui, em linha gerais, a seguinte questão: Marx e Engels são autores de uma estética? A despeito das teorias da arte marxistas que tem procurado suas fontes em sua obra - o que não é nada ilegítimo - é preciso, todavia, começar afirmando que não é possível encontrar uma estética marxiana. Esta 
ausência é consequência da redefinição geral do trabalho teórico empreendido por Marx e Engels que inviabiliza tanto a constituição de uma filosofia separada quanto a elaboração de uma estética em si. A definição permanece sujeita a esta mesma tradição filosófica.

No entanto, a questão da arte surge regularmente, ao longo de toda a obra dos autores e em pontos cruciais da análise. Paralelamente às numerosas citações de poemas, de tragédias e de romances, e aos comentários literários que salpicam a obra e as correspondências de Marx e Engels, é antes de tudo como atividade social que a criação artística se encontra abordada e sistematicamente religada às demais questões: aquela do trabalho subsumido ao modo de produção capitalista e aquela do desenvolvimento não alienado das faculdades individuais.

É a partir deste ângulo, efetivamente, que a aproximação marxiana da arte, a despeito de seu caráter episódico e incompleto, se revela mais original, associando a análise de uma atividade social de um gênero particular, a produção artística, à uma crítica global e concreta da alienação. Se seguirmos esta via, ao longo de toda a vasta obra de Marx e Engels, evidenciaremos o estatuto problemático da atividade artística que sua obra revela. Este estatuto se atém a uma dupla necessidade:1) conceber a atividade artística como possibilidade efetiva, mas excepcional e isolada, de uma atividade humana livre da alienação; 2) conceber a atividade artística como atividade socialmente determinada pelas formações históricas onde ela se localiza, formações caracterizadas pelas relações de dominação e exploração que culminam no modo de produção capitalista. Esta análise se efetua em diversos momentos, sem ruptura, mas no ritmo das etapas maiores que escandem e perpassa toda a sua obra.

Assim como nos autores apresentados, apesar de não encontrarmos em Marx e Engels uma sistematização da teoria estética, essa deve ser analisada e compreendida considerando os pressupostos gerais estabelecidos pelos autores para se pensar o processo de desenvolvimento histórico.

Diferentemente das proposições de Hegel, que pensa o desenvolvimento histórico em termos teleológicos na qual a história nada mais é que o lócus onde o espírito se desvela e através da qual as contradições no campo das ideias são apenas momentos determinados do processo de evolução e desenvolvimento do espírito, Marx e Engels concebem a história como o campo onde as lutas reais entre as classes sociais acontecem. 
Neste sentido, a "história de todas as sociedades até hoje existentes é a história das lutas de classes" (MARX e ENGELS, 2010, p. 40). A contradição que caracteriza o movimento histórico é real e concreto, atinge todos os indivíduos sociais determinando e condicionando suas ações, seus pensamentos, sua ética, sua política e assim por diante.

Todos os complexos sociais devem, portanto, ser analisados a partir dessa premissa fundamental, qual seja, as contradições sociais. Por esse prisma, a produção artística e o seu produtor devem, antes, ser analisados como um desdobramento das próprias contradições sociais.

Evidentemente, nos primórdios do processo de humanização, quando o proto-homem se encontrava totalmente subordinado em relação as condições naturais, vivendo como coletores e, no máximo, caçadores, todas as forças da generidade muda estavam voltadas para sobrevivência e reprodução orgânica do gênero mudo. Segundo Vaisman e Fortes,

Segundo o filósofo húngaro a categoria da generidade explicita a concepção revolucionária sobre o ser e o devir humano instaurada por Marx. Lukács identifica o lugar genético dessa concepção, isto é, da superação do gênero mudo natural e o advento do gênero propriamente humano, precisamente na práxis que constitui o modo por meio do qual se processa a "adaptação ativa" e a partir da qual se dá, de modo contraditório e desigual, a constituição processual do ser social. Em outros termos, "a base ontológica do salto [do gênero mudo para o gênero não-mais-mudo] foi a transformação da adaptação passiva do organismo ao ambiente em uma adaptação ativa, com o que a sociabilidade surge como nova maneira de generidade (2010, p. 27).

Somente após um longo e gradual processo de desenvolvimento, sobretudo após a Revolução Neolítica com a sedentarização dos povos, o desenvolvimento da agricultura e a domesticação de animais, ou seja, a partir da produção de excedentes produtivos é que uma parte da força de trabalho foi liberada para criar "livremente" sua odisseia.

Evidentemente, estamos caminhando por aquilo que Marx e Engels (2007) conceituaram como divisão entre trabalho material e espiritual que deve ser igualmente analisada a partir da premissa das contradições sociais. Se o primeiro é voltado para produção de artigos cuja função é suprimir as necessidades primárias que viabilizam o processo de reprodução social dos homens, ou seja, os artigos de primeira necessidade e, posteriormente, os supérfluos, o segundo está dirigido para os elementos da superestrutura, tais como política, filosofia, teologia e, por conseguinte, para a produção estética. Vale salientar que 


\begin{abstract}
A divisão do trabalho só se converte em verdadeira divisão a partir do momento em que se separam os trabalhos material e espiritual. A partir desse momento, a consciência já pode imaginar que é algo a mais e algo distinto dessa práxis vigente, pode realmente representar alguma coisa sem representar algo real - a partir deste momento a consciência se acha em condições de se emancipar do mundo e se entregar à criação da teoria "pura", da teologia "pura", da filosofia "pura", da moral "pura" etc. (MARX e ENGELS, 2007, p. 54).
\end{abstract}

Ora, para que alguns homens possam se dedicar exclusivamente ao campo da produção espiritual é preciso que outros assegurem-lhes as condições necessárias e primárias da reprodução social. Somente a partir deste momento, os diversos complexos sociais puderam se desenvolver em uma aparente autonomia em relação a base material da sociedade. A criação artística em seus diversos campos deve ser analisada, inicialmente, como fruto dessa condição primária da sociedade que desemboca, inevitavelmente, numa divisão entre as classes sociais, ou seja, entre aqueles indivíduos que se apropriam do excedente produtivo e aqueles que tem seu excedente expropriado.

Foi partindo dessa premissa que Marx e Engels afirmaram que - no bojo da discussão sobre a afirmação da individualidade e do individualismo burguês (momento determinado de afirmação da generidade não-mais-muda (LUKÁCS, 2012) - mesmo aquelas atividades que parecem ser personalíssimas, cujo produto final só poderia resultar da máxima afirmação da singularidade e da "genialidade" de um determinado sujeito histórico são, também elas, inevitáveis expressões da divisão social do trabalho e das contradições sociais.

Estando as inferências dos autores correta, implica dizer que os grandes artífices da literatura mundial, da música e das artes em geral, que foram capazes de manifestar, através de suas obras, uma grande síntese peculiar das determinações históricas do seu tempo, só se tornaram competentes para tal realização a partir da divisão inicial entre trabalho material e trabalho intelectual que se prolongou historicamente na qual eles estiveram, inevitavelmente, inseridos. Aquilo que poderia ser visto como fruto da genialidade humana torna-se, a partir deste entendimento, um desdobramento particular das sociedades de classes, que favorece o desenvolvimento de certas habilidades em uns, enquanto outros são privados dessas mesmas habilidades. É neste contexto que os autores de A ideologia alemã afirmarão de forma peremptória e sem margens para erros:

Revista RBBA $\mid$ Revista Binacional Brasil Argentina 
Sancho imagina que Rafael pintou seus quadros independentemente da divisão do trabalho que havia em Roma em seu tempo. Se ele comparar Rafael com Leonardo Da Vinci e Ticiano, poderá ver até que ponto as obras de arte do primeiro se achavam condicionadas pelo florescimento a que Roma havia chegado na época, sob a influência de Florença, como mais tarde as do terceiro foram condicionadas pelo desenvolvimento - totalmente distinto, seja dito - de Veneza. Rafael, nem mais nem menos do que qualquer outro artista, achava-se condicionado pelos progressos técnicos da arte alcançados antes de ele chegar, pela organização da sociedade e pela divisão do trabalho dentro de sua localidade, e finalmente, pela divisão do trabalho em todos os países com os quais sua localidade mantinha relações de intercâmbio (MARX \& ENGELS, 2007, p. 443).

Nesta citação dois elementos cruciais precisam ser observados. O primeiro refere-se aquele já explorado na anterioridade do texto relativo a subordinação da produção artística aos imperativos da divisão social do trabalho; o segundo, por sua vez, traz à baila os condicionamentos materiais do artífice (em geral) na sociedade de classe em relação a sua produção artística. Em outras palavras, nenhuma produção humana está além do tempo histórico no qual foi produzida, constituindo, antes, uma síntese materializada pela apropriação/subjetivação singular realizada pelo sujeito em seu devir histórico.

Isso significa que uma personagem como Hérmia de Shakespeare (2001) em Sonho de uma noite de verão só poderia ser representada ousando desafiar o seu destino a ponto de ensaiar fugir com Lisandro em um tempo histórico no qual tal realização fosse possível. Portanto, entender as representações teatrais das obras do autor citado implica, inevitavelmente, considerar as determinações sociohistóricas daquilo que ficou conhecido como renascimento cultural e comercial, a partir das quais surgiu uma proto-transformação social que se aventurava a questionar os estamentos e o direito de nascença peculiar do medievo cristão. Não sem razão, Lukács afirma que

O ponto comum e significativo do ponto de vista ontológico reside em que, em todos os casos, por mais díspares que sejam, trata-se de como o respectivo artista possui em si um mundo pessoal que brota espontaneamente de sua generidade em si e que ele usa no processo de criação, visando à superação consumada na práxis de sua própria particularidade (aceitação acrítica da respectiva generidade em si), e como ele, desse modo, enquanto criador, se torna uma personalidade não mais particular. Assim Balzac, um homem com simpatias reacionárias de cunho monarquista, torna-se o grande crítico sintético da civilização capitalista; assim Tolstoi, um aristocrata que nutre simpatias sentimentais pelos camponeses, torna-se porta-voz de um humanismo democrático-plebeu e, em consequência disso, chega a uma crítica demolidora da sociedade de classes. Essa concepção fundamental para o papel histórico-universal da arte é compartilhada, em seus traços 
essenciais, por muitos grandes artistas, especialmente em sua práxis, mesmo que terminologicamente muitas vezes se expressem de modo bem diferente quando de fato chegam a abordar esse problema teoricamente e não o realizam apenas na práxis (2013, p. 445-446).

Em outras palavras, podemos inferir que Shakespeare realizou, em suas obras, uma grande síntese que manifesta o tempo inteiro, no seu interior, as múltiplas determinações sociais, sejam elas políticas, religiosas, artísticas (metalinguísticas) e econômicas vigente no seu tempo histórico. Por este prisma, uma obra artística jamais deve ser analisada como uma representação autônoma no tempo e no espaço. Se não podemos reduzir a obra de arte à representação abstrata e desconexa da totalidade social, tampouco ela constitui uma realidade autônoma.

Se lembrarmos que Rafael é venerado como o mais inspirado dos pintores pelos Nazarenos, compreenderemos que a crítica de Marx e Engels visa não apenas Stirner, mas toda a estética dominante contra a qual se está lutando. Nessa ruptura radical com esta forma de arte e com o idealismo filosófico, de modo geral, fica evidente que a organização social da produção constitui a base determinante a partir da qual podemos compreender o conjunto das atividades humanas. No contexto desta análise, a questão da arte se transforma mais uma vez: se a arte como atividade é ela mesma um eco do mundo da produção que lhe é contemporânea, importa, antes de mais nada, encará-la como uma prática social em meio as demais práticas.

Esta forma de conceber a arte se deve ao fato de que, na Ideologia alemã, a arte não gozar do caráter excepcional próprio de uma atividade que seria, integralmente, emancipadora: restituída no quadro da divisão do trabalho, ela deixa de ser um modelo de libertação para tornar-se, mais modestamente, um dos objetos de explicação histórica. É este pressuposto que está implícito nas análises de Marx e Engels e o que, de fato, eles se esforçam por construir, como referencial capaz de situar a produção artística no contexto da história.

Assim, se o tema da arte se faz também lateral, como o tema persiste no interior da obra marxiana, é porque, no mesmo quadro referencial de toda atividade, ela deve ser recolada no contexto econômico e social que é o, no fundo, religada à uma perspectiva revolucionária e emancipadora. Assumindo este ponto de partida, a posição dos artistas não é nem de 
primeiros atores, nem de principais portadores, dado o fato de que eles gozam de uma relativa proteção, face aos desgastes humanos produzidos pela organização capitalista de produção.

Não quer dizer que os artistas estão excluídos e possam formar um grupo marginal e sim afirmar que eles, assim como todos os demais trabalhadores, estão inseridos no modo de produção que é próprio à sua sociedade. Por isso mesmo é preciso concluir que a noção de gênio, cara aos românticos, assim como à estética das Luzes, é abandonada. Se a excepcionalidade suposta dos criadores é devotada a subtrair-se aos estudos históricos do modo de produção artística, toda atividade histórica, pois humana, estaria destinada a se perder toda a possibilidade de manifestação de si, na história. Esta tese é enfaticamente defendida por um especialista reconhecido da estética de Marx, Adolfo Sánchez Vásquez:

A arte, como dissemos, é criação de objetos que satisfazem essencialmente
uma necessidade meramente espiritual, isto é, objetos afastados não apenas
da mera necessidade física, imediata, mas da necessidade prática satisfeita
pelos produtos do trabalho. [...]. O trabalho é assim, histórica e socialmente,
a condição necessária do aparecimento da arte, bem como da relação estética
do homem com seus produtos (VÁSQUEZ, 1968, p. 72-73).

O problema se apresenta, então, muito mais complicado do que uma visão ingênua sobre a arte pode fazer sugerir. Não se trata de negar o talento artístico ou reconhecer em cada indivíduo um Rafael. Marx e Engels mantêm o reconhecimento do talento artístico como criatividade superior. No entanto, não deixam de estabelecer uma ligação deste talento com as relações sociais efetivas nas quais o artista está inserido. O conhecimento teórico sobre a arte, bem como as práticas de atelier que estão em voga e são utilizados pelo artista é um elemento importante não somente para possibilitar a manifestação, mas também para circunscrever, histórica e socialmente a realização do artista como parte da realização do homem como ser genérico. Marx e Engels reconhecem plenamente que

A concentração exclusiva do talento artístico em indivíduos únicos e a consequente opressão desses dotes na grande massa são um resultado da divisão do trabalho. Se, até mesmo sob certas condições sociais, todos pudessem chegar a ser um cantor magnifico, isso estaria longe de excluir que todos fossem um pintor original, de modo que também aqui a diferença entre trabalho "humano" e trabalho "único" estaria reduzida a um puro absurdo (MARX E ENGELS, 2007, p. 444).

Depreende-se, a partir do texto lido, que dois temas, descritos em relativa tensão recíproca, se superpõe. De um lado, o trabalho artístico é, como todo e qualquer trabalho, 
dependente da organização conjunta da produção. Neste registro, ele não goza de nenhum privilégio. De outro, Marx e Engels fazem do artista uma exceção: ele é um dos raros homens a desenvolver seu poder criativo. Neste sentido a crítica se volta não apenas sobre o caráter especializado deste talento único, mas pelo fato de que diz respeito apenas a uma parte das faculdades humanas e, sobretudo, de uma fração da humanidade. Mas os dois argumentos não são, de modo algum, da mesma ordem: de um lado, o pintor é um trabalhador como qualquer outro; de outro, ele é ao menos o esboço do indivíduo completo, cujo figura aparece a partir de sua obra: "Em uma sociedade comunista não haverá pintores, mas sim no máximo homens que, entre outras coisas, ocupam-se de pintar" (MARX E ENGELS, 2007, p. 444).

Marx e Engels não poderiam expressar melhor o caráter contraditório de uma prática social que sofreu a alienação e teme as vias de sua abolição. A arte parece ser, a um só tempo, determinada e autônoma, alienada e libertadora; eco das contradições do real e fermento revolucionário de seu ultrapassamento. É claro que a questão, tal como está formulada aqui, exige uma retomada e posteriores desenvolvimentos. É no curso de um terceiro e último momento que Marx e Engels se esforçam para conciliar esta dupla intuição da arte como atividade social determinada e o como desenvolvimento excepcional de alguns indivíduos prefigurando uma sociedade do futuro. A ligação entre arte e trabalho fica restrita, sem tornarse algo idêntica: ao contrário, a tensão dos dois componente da atividade artística parece conduzir Marx a definir melhor aquilo que poderia ser a supressão da alienação e da exploração, sem seguir o pendor utópico mais ao se apoiar sobre esta crítica imanente e concreta da alienação que é em si mesma a individualidade excepcional do artista. Como bem sintetizou Lukács,

[...] a arte, no sentido ontológico, é uma reprodução do processo mediante o qual o homem compreende a própria vida, na sociedade e na natureza, como vida que se refere a si mesmo, com todos os problemas e com todos os princípios vantajosos e todos os obstáculos que a determinam (LUKÁCS, 2014, p. 41-42).

De toda sorte, a capacidade de criação humana, dentro do quadro exclusivo das sociedades de classes, deve ser analisada sempre no interior deste conjunto de relações sociais descritas por Marx e Engels como fruto da divisão do trabalho, em última instância, entre trabalho material e intelectual. Assim, é a divisão social do trabalho que cria os 
condicionamentos para que determinados talentos artísticos sejam desenvolvidos em uns e suprimidos em outros.

Portanto, há em Marx e Engels uma refutação peremptória de toda a tradição filosófica que explicou a produção artística, através da teoria do gênio. Aqueles sujeitos que são chamados de gênios não são outra coisa, senão, a expressão e o desdobramento mais peculiar dos imperativos e das contradições sociais.

Entrementes, os autores pensam na possibilidade de construção e desenvolvimento da subjetividade humana na qual os afloramentos de determinados talentos não estejam condicionados por tal divisão. Formulam, assim, que

[...] em uma organização comunista da sociedade desaparece a subsunção do artista à limitação local e nacional, que responde pura e unicamente à divisão do trabalho, e a subsunção do indivíduo a essa arte determinada, de tal modo que apenas haja exclusivamente pintores, escultores e assim por diante [...]. Em uma sociedade comunista não haverá pintores, mas sim no máximo homens que, entre outras coisas, ocupam-se de pintar (MARX \& ENGELS, 2007, p. 444).

Assim, numa radicalização da proposta humanista, os autores postulam que o livre desenvolvimento das potencialidades humanas só pode ocorrer numa sociedade emancipada e livre dos processos de alienação social.

\section{Considerações finais}

Muito embora a tradição filosófica tenha tratado do problema da arte e do artista a partir de uma perspectiva idealista, na medida em que as condições e os condicionamentos materiais foram negligenciados, não podemos negar que cada um dos autores tratados deu sua parcela de contribuição para o entendimento do problema buscando articular com a totalidade dos seus respectivos sistemas filosóficos.

Entretanto, é na modernidade, principalmente com Hegel e Marx e Engels que a produção artística ganha uma dimensão eminentemente histórica. Se, porém, a dimensão estética ainda está perpassada pelo entrelaçamento "quântico" do revelar-se do espírito no mundo a partir das inferências hegelianas, em Marx e Engels, por outro lado, ela ganha contornos estritamente histórico-material relacionada, intrinsecamente, com as condições objetivas de reprodução social. 
Essa contraposição marxiana à teoria do gênio conduz a conclusão dos defensores desta teoria. Agora toda a produção estética deve ser analisada, não como um momento da manifestação do espírito no mundo, mas, contrariamente, como a manifestação peculiar e determinada pelos condicionamentos sociais na qual se expressa as contradições e a perspectiva de classe. A arte, assim, não pode ser algo nem além nem aquém do seu artífice. $\mathrm{O}$ artífice, por sua vez, não poderá jamais estar nem além nem aquém das determinações estruturais da sociedade na qual está inserido, ainda que goze de uma autonomia relativa.

É, portanto, inconcebível pensar, a partir de Marx e Engels, considerando todas as premissas do materialismo histórico postuladas por esses autores, qualquer relação entre a produção artística e a formulação clássica estabelecida pela tradição filosófica em termos de uma teoria do gênio. Em uma concepção materialista da história não há lugar para os gênios, nem para os dons, nem para as inspirações transcendentais, mas unicamente para a explicação de tais elementos a partir dos condicionamentos materiais que imperam sobre os sujeitos e sua relação com a forma singular com a qual cada sujeito reage diante de tais objetividade. Essa relação entre a objetividade e a subjetividade deve ser o elemento explicativo das potencialidades peculiares que emergem no mundo, sem a necessidade de buscar fora uma explicação para os fenômenos artísticos uma vez que eles estão subsumidos no processo histórico.

\section{Referências}

ABBAGNANO, Nicolas. Dicionário de filosofia. Tradução de Alfredo Bossi e revisão da tradução e tradução de novos textos de Ivone Castilho Benedetti. 5 ed. São Paulo: Martins Fontes, 2007.

ARISTÓTELES. O homem de gênio e a melâncolia: problema XXX, V. 1. Saõ Paulo: Lacerda, 1998. Edipro, 2012.

Parva Naturalia. Tradução de textos adcionais e notas de Edson Bini. Bauru, SP: Ética a Nicomaco. 2 ed. Forense Universitária, 2016.

Poética. Tradução de Paulo Pinheiro. São Paulo: Editora 34, 2015. 
BACCOU, Robert. Introdução e notas. In: PLATÃO A República. São Paulo: Difusão européia do livro, 1965, p. 5-63.

BURGEOIS, B. Hegel: os atos do espírito. São Leopoldo: Unisinos , 2004.

CHAUÍ, M. Introdução à história da filosofia: dos pré-socráticos a Aristóteles. 2 ed. rev. e ampl. ed. São Paulo: Companhia das Letras, v. 1, 2002.

DETIENNE, Marcel. Mestres da verdade na Grécia arcaica. São Paulo: Martins Fontes, 2013.

HEGEL, G. W. F. Curso de estética I. Tradução de Marcos Aurélio Werle. 2 ed. São Paulo: Editora Universidade de São Paulo, v. I, 2001.

Fenomenologia do Espírito. 8 ed. Petrópolis: Vozes, 2013.

KANT, I. Crítica da faculdade de julgar. Tradução de Fernando Costa Matos. Petrópolis: Vozes; Bragança Paulista: Editora Universitária São Francisco, 2016.

LUKÁCS, G. Prolegômenos para uma ontologia do ser social: questões de princípios para uma ontologia hoje tornada possível. Tradução de Lya Luft e Rodnei Nascimento e supervisão editorial de Ester Vaisman. São Paulo: Boitempo, 2010.

. Para uma ontologia do ser social. Tradução de Ivo Tonet, Ronaldo Vielmi Fortes Nélio Schineider. São Paulo: Boitempo, 2013.

Conversando com Lukács: entrevista a Léo Kofler, Wolfgang Abendroth e Hans Heinz Holz. Tradução de Gisieh Vianna. São Paulo: Instituto Lukács, 2014.

MARX, Karl, e ENGELS, Friedrich. A Ideologia Alemã: crítica da novissima filosofia alemã em seus representantes Feuerbach, B. Bauer e Stirner, e do socialismo alemão e seus profetas. São Paulo: Civilização Brasileira, 2007.

Manifesto Comunista. Tradução de Alvaro Pinto e Ivana Jinkings. $1^{\circ}$ ed. revista. ed. São Paulo: Boitempo, 2010.

NÓBREGA, Francisco Pereira. Para Compreender Hegel. 7 ed. Petrópolis: Vozes, 2011.

NUNES, Carlos Alberto. Tradução e introdução. In: HOMERO. Ilíada. Tradução de Alberto Nunes. 25 ed. ed. Rio de Janeiro: Nova Fronteira, 2015, p. 7-54.

OLIVEIRA, Cláudio. Introdução. In: PLATÃO. Íon. Belo Horizonte: Autêntica, 2011, p. 1122.

PINHEIRO, Paulo. Introdução e notas. In: ARISTÓTELES. Poética. São Paulo: Editora 34, 2015, p. 7-33.

PLATÃO. A república. 4 ed. Belém: Ufpa, 2016a [Bilingue].

Íon. Tradução de Cláudio Oliveira. Belo Horizonte: Autêntica Editora, 2011.

\begin{tabular}{l|l} 
Revista RBBA & Revista Binacional Brasil Argentina
\end{tabular} 
2001.

Mênon. Tradução de Maura Iglésias. Rio de Janieiro: Puc-Rio; São Paulo: Loyola,

Diálogos II: Górgias (ou Da Retórica); Eutidemos (ou Da Disputa); Hípias Maior (ou do belo); Hípias Menor (ou do falso). Tradução, textos adicionais e notas de Edson Bini. 2 ed. São Paulo: Edipro, 2016b.

Diálogos III: (socráticos): Fedro (ou do belo); Eutífron (ou da religiosidade); Apologia de Socrátes; Críton (ou do dever); Fédon (ou da alma). Tradução de textos complementares e noras Edson Bini. Bauru: Edipro, 2008.

. Diálogos V: o banquete; Mênon (ou da virtude); Timeu; Critias. Tradução de textos complementares e nota Edson Bini. Bauru, SP: Edipro, 2010.

SHAKESPEARE. W. Sonho de uma noite de verão. São Paulo: L\&PM, 2001.

VÁSQUEZ, Adolfo Sánchez. As idéias estéticas de Marx. Rio de Janeiro: Paz e Terra, 1968.

VAISMAN, E. E FORTES, R. V. Apresentação. In: LUKÁCS, G. Prolegômenos para uma ontologia do ser social: questões de princípios para uma ontologia hoje tornada possível. Tradução de Lya Luft e Rodnei Nascimento e supervisão editorial Ester Vaisman. São Paulo: Boitempo, 2010, p. 9-30.

Notas

\footnotetext{
' Evidentemente formulações que considere 'mais belas' as artes associadas à cultura burguesa só podem advir de uma ideia de hierarquia e evolução no fazer artísticos e na própria arte, entendendo as últimas mais evoluídas que as primeiras. Essa concepção, claro, é indissociável da divisão de classes inerente a sociabilidade burguesa.

ii Não constitui objetivo deste ensaio discutir a relação da sofística com o saber filosófico.

iii Chamamos atenção aqui para que não se confunda capacidade com criatividade, um a vez que um escultor pode ser profundamente capaz de executar uma obra, mas que tal obra não traga na sua composição a materialização da criatividade.

${ }^{\text {iv }}$ Hegel refere-se ao movimento pré-romântico Sturm und Drang [Tempestade e ímpeto] (N. da T).

${ }^{v}$ Vale ressaltar que, para Kant, existem três expressões das belas artes, sendo elas as artes discursivas (a retórica e a poesia), as artes figurativas de verdade sensível ou aparência sensível sendo a primeira a arte plástica e a segunda a pintura e, por fim, aquilo que o autor denomina de "arte do belo jogo das sensações" (KANT, 2016, pp. 218-223).
}

\section{Sobre os autores}

Alexandre de Jesus Santos. Graduado em História e Mestre em Memória: Linguagem e Sociedade, pela Universidade Estadual do Sudoeste da Bahia; doutorando em Memória e graduando em Filosofia pela mesma instituição; Membro do Grupo de Estudos de Ideologia e Luta de Classes - GEILC/CNPq. Tem experiência na área de Filosofia, com ênfase em Filosofia Contemporânea, 
teoria da memória, reprodução social, lutas de classes, ideologia, alienação e emancipação humana. Bolsista da Fundação de Amparo à Pesquisa do Estado da Bahia FAPESB. Endereço Eletrônico: alexandre_magno2@hotmail.com

Jasson da Silva Martins. Professor Assistente da Universidade Estadual do Sudoeste da Bahia (UESB). Licenciado em Filosofia pelo Centro Universitário La Salle (UNILASALLE). Mestre em filosofia pela Universidade do Vale do Rio dos Sinos (UNISINOS). Desde 2011 é professor Assistente B da UESB, lotado no DFCH e membro do Colegiado do curso e da Área de filosofia. Além de lecionar as disciplinas de História da filosofia antiga, Estética e Metafísica, desenvolve o seguinte projeto de Pesquisa: "Da poética do trágico à filosofia da tragédia". O referido projeto de pesquisa visa a estabelecer, através da reconstrução do contexto teórico, a relação entre o nexo histórico-filosófico, que permite apresentar a passagem da poética da tragédia (Aristóteles), à filosofia da tragédia (Nietzsche). Endereço Eletrônico: jassonfilos@gmail.com 